\title{
MEDIA POHON BERHITUNG UNTUK MENINGKATKAN AKTIVITAS BELAJAR SISWA SEKOLAH DASAR
}

\author{
Siti Kurniati 1, Melkyanus Bili Umbu Kaleka², Maria Alberta Liza Quintarti ${ }^{3}$ \\ 1,2,3Universitas Flores, Ende, Indonesia \\ *Penulis Koresponsensi, email: sitikurniayanti543@gmail.com
}

Article History

$\begin{array}{lll}\text { Received:12/11/2020 Revised:14/11/2020 Accepted:15/11/2020 } & \text { R }\end{array}$

\begin{abstract}
Learning from home is a step taken in dealing with conditions that occur due to Corona Virus 19. One of the methods applied is to form study groups with varying frequency of teacher visits. This of course requires energy and time so that learning is more effective and efficient. Lack of mentoring by the teacher causes students to spend time playing. Through real work lectures, students of the Elementary School Teacher Education study program developed an innovative learning media, namely a counting tree to increase the learning activities of grade 1 elementary school students. This solution is taken so that students can fill their learning time while playing. The expected results after this service activity, teachers and parents can use learning media to guide students at home, and enable teachers to innovate in developing learning media.
\end{abstract}

Keywords: Learning media, Counting Trees, Real Work Lecture Learning Activities

\begin{abstract}
Abstrak. Belajar dari rumah merupakah langkah yang diambil dalam menghadapi kondisi yang terjadi akibat Corona Virus 19. Salah satu cara yang diterapkan adalah dengan membentuk kelompok belajar dengan ferkuensi kunjungan guru yang bervariasi. Hal ini tentunya membutuhkan tenaga dan waktu agar pembelajaran lebih efektif dan efisien. Kurangnya pendampingan oleh guru menyebabkan siswa menghabiskan waktu dengan bermain. Melalui kegiatan kuliah kerja nyata, mahasiswa program studi Pendidikan Guru Sekolah Dasar, mengembangakn sebuah media pembelajaran inovatif yaitu pohon berhitung untuk meningkatkan aktivitas belajar siswa kelas 1 sekolah dasar. Solusi ini diambil agar siswa dapat mengisi waktu belajar sambil bermain. Hasil yang diharapan setelah kegiatan pengabdian ini, guru maupun orang tua dapat memanfaatkan media pembelajaran untuk membimbing siswa di rumah, serta memampukan guru untuk berinovasi dalam mengembangkan media pembelajaran.
\end{abstract}

Kata Kunci : Media pembelajaran, Pohon Berhitung, Aktivitas Belajar Kuliah Kerja Nyata

How to Cite: Kurniati, S., Kaleka, M. B. U., \& Quintarti, M. A. L. (2020). MEDIA POHON BERHITUNG UNTUK MENINGKATKAN AKTIVITAS BELAJAR SISWA SEKOLAH DASAR. Mitra Mahajana: Jurnal Pengabdian Masyarakat, 1(1), $70-76$. https://doi.org/10.37478/mahajana.v1i1.722

\section{PENDAHULUAN}

Tujuan pendidikan pada dasarnya mengantarkan para siswa menuju pada perubahanperubahan tingkah laku baik intelektual, moral, maupun sosial anak agar dapat hidup mandiri sebagai individu dan mahluk sosial. Dalam mencapai tujuan tersebut siswa berinteraksi dengan lingkungan belajar yang diatur guru melalui proses pembelajaran. Lingkungan belajar yang diatur oleh guru mencakup tujuan pembelajaran, bahan pembelajaran, metodologi pembelajaran, dan penilaian pembelajaran. Secara khusus terkait metodologi pembelajaran, aspek ini terkait dengan dua hal yang saling menonjol yaitu metode dan media pembelajaran. Media memiliki kedudukan yang sangat penting dalam mencapai tujuan pembelajaran secara efektif (Zaman et al., 2010). Media dalam proses pembelajaran dapat mempertinggi proses belajar siswa dalam pembelajaran yang pada gilirannya diharapkan dapat mempertinggi hasil belajar yang dicapainya. Berbagai penelitian yang dilakukan terhadap penggunaan media dalam pembelajaran sampai pada kesimpulan, bahwa proses dan hasil belajar pada siswa menunjukkan perbedaan yang signifikan antara pembelajaran tanpa media dengan pembelajaran menggunakan media. Oleh karena itu penggunaan media pembelajaran sangat dianjurkan untuk meningkatkan kualitas pembelajaran. 
Media pembelajaran saat ini merupakan hal mendesak yang wajib dimiliki guru dalam proses pembelajaran. Media pembejaran bukan lagi sebagai pelengkap guru untuk menyampaikan informasi kepada siswa dalam melaksanakan kegiatan belajar mengajar, tetapi dapat menjadi pengkondisi dalam berprestasi (Mahnun, 2012).

Media merupakan alat yang dapat digunakan sebagai perantara dalam menstimulasi semua aspek perkembangan pada anak usia dini baik aspek nilai moral dan agama, aspek fisik motorik, aspek bahasa, aspek sosial emosional, aspek kognitif maupun aspek seni. Dalam mesntimulasi aspek perkembangan anak usia dini harus disesuaikan dengan usia dan tahapan perkembanganya karena setiap anak walaupun memiliki usia yang sama tapi terkadang memiliki tahap perkembangan yang berbeda. Untuk merangsang semua aspek perkembangan anak usia dini tidak bisa lepas dari media pembelajaran karena bagi anak usia dini belajar dilakukan melalui bermain dengan menggunakan media pembelajaran baik media nyata, media audio, media visual, media lingkungan sekitar maupun media audio visual, sehingga kegiatan pembelajaran pada anak usia dini berjalan secara efektif (Zaini \& Dewi, 2017).

Salah satu jenis media pembelajaran yang dapat dugunakan untuk mempelajari materi penjumlahan pada siswa sekolah dasar adalah media pohon berhitung. Jenis media ini merupakan modivikasi atau pengembangan dari media pohon pintar yang digunakan bagi anak usia dini 1 - 6 tahun (anak PAUD).Media pohon pintar juga merupakan media yang mengandung segi estetika dan keindahan (Mukhtar Latif, 2013). Keterkaitan media pohon pintar terhadap kemampuan berhitung adalah ketika dilihat dari hasil yang menunjukkan peningkatan kemampuan berhitung setelah menggunakan media tersebut. Anak akan merasa senang dan proses pembelajaran menjadi lebih menarik dan menyenangkan. Hendaknya seorang tenaga pendidik yang professional harus memahami karakteristik isi pesan pembelajaran yang akan disampaikan, agar tidak salah dalam memilih strategi pembelajarannya, interaksi pembelajaran, pengelolaan kelas, pemilihan bahan pembelajaran dan media pembelajaran, serta alat evaluasi yang akan digunakan (Hernawan et al., 2008).

Sejak diberlakukannya belajar dari rumah akibat corona virus 19 yang dialami dunia sejak awal tahun 2020, maka dibutuhkan kerja sama yang lebih maksimal antara guru dan orang tua. Pengajaran tidak dapat terlaksana dengan baik tanpa adanya interaksi antar komponen pembelajaran, maka semua komponen pembelajaran harus bekerjasama untuk mewujudkan pembelajaran yang efisien (Pane \& Darwis Dasopang, 2017). Peran yang sangat strategis dalam optimalisasi pendidikan usia dini adalah peran orang tua (Purnomo, 2013).

Kondisi yang terjadi di desa Ndetuzea kecamatan Nangapanda kabupaten Ende, propinsi Nusa Tenggara Timur (NTT), menunjukkan bahwa sebagian besar siswa sekolah dasar yang ada di desa tersebut menghabiskan waktu di rumuh dengan bermain. Kurangnya pengawasan orang tua serta keterbatasan guru dalam membimbing siswa, menjadi salah satu kendala dalam kegiatan belajar siswa. Di desa Ndetuzea, mayoritas penduduk memiliki mata pencaharian sebagai petani, sehingga sebagian besar orang tua harus berkebun sepanjan hari. Waktu belajar dari rumah yang telah diatur oleh guru sekolah, tidak terjadi setiap hari, tetapi 2 - 3 kali dalam satu minggu. Untuk mengatasi permasalahan ini, salah satu langkah yang dapat diambil adalah dengan mengembangakan atau membuat media belajar yang dapat digunakan siswa dalam belajar secara mandiri.

Dengan adanya kegiatan Kuliah Kerja Nyata (KKN) Mandiri, mahasiswa Program Studi Pendidikan Guru Sekolah Dasar (PGSD), mengambil langkah kegiatan pengabdian bagi siswa Sekolah Dasar untuk tetap belajar sambil bermain menggunakan media pohon berhitung. Solusi yang diambil untuk mengatasi permasalahan di atas adalah;

1. Membuat media pembelajaran yaitu pohon berhitung.

2. Membuat jadwal belajar bagi siswa untuk belajar mandiri dan juga dibimbing oleh orang tua. 
Target luaran yang diharapkan melalui kegiatan pengabdian ini adalah;

1. Menghasilkan media pembelajaran pohon berhitung

2. Terlaksananya bimbingan belajar bagi siswa oleh orang tua sesuai jadwal belajar yang dibuat.

\section{METODE PELAKSANAAN}

Metode pelaksanaan kegiatan yaitu dalam bentuk kegiatan Kuliah Kerja Nyata (KKN) Mandiri yang dilaksanakan di desa Ndetuzea Kecamatan Nangapanda Kabupaten Ende, selama 1 bulan yaitu dari tanggal 03 agustus sampai 03 september 2020. KKN Mandiri yaitu kegiatan dimana mahasiswa secara mandiri mencari desa/kelurahan sebagai tempat pelaksanaan KKN. Pelaksanaan kegiatan disesuaikan dengan tema yang diberikan, salah satunya adalah Inovasi dan Teknologi Pembelajaran. Melalui kegiatan pengabdian ini, dalam rentang waktu satu bulan penuh mahasiswa berada di lokasi KKN. Selain melaksanakan kegiatan pembelajaran sebagai tema utama, terdapat berbagai kegiatan pengabdian yang dilaksanakan di desa Ndetuzea. Sebagai bagian dari kegiatan KKN.

Langkah-langkah yang dilakukan untuk membuat media pembelajaran pohon berhitung adalah;

1. Menyiapkan alat dan bahan antara lain; gunting, kerta karton berwarna, dos/gardus bekas, lem kertas, dan spidol.

2. Membuat pola pohon dan juga berbagai asesoris yang menarik sehingga disenangi siswa. Contoh dapat dilihat pada Gambar 1.

3.

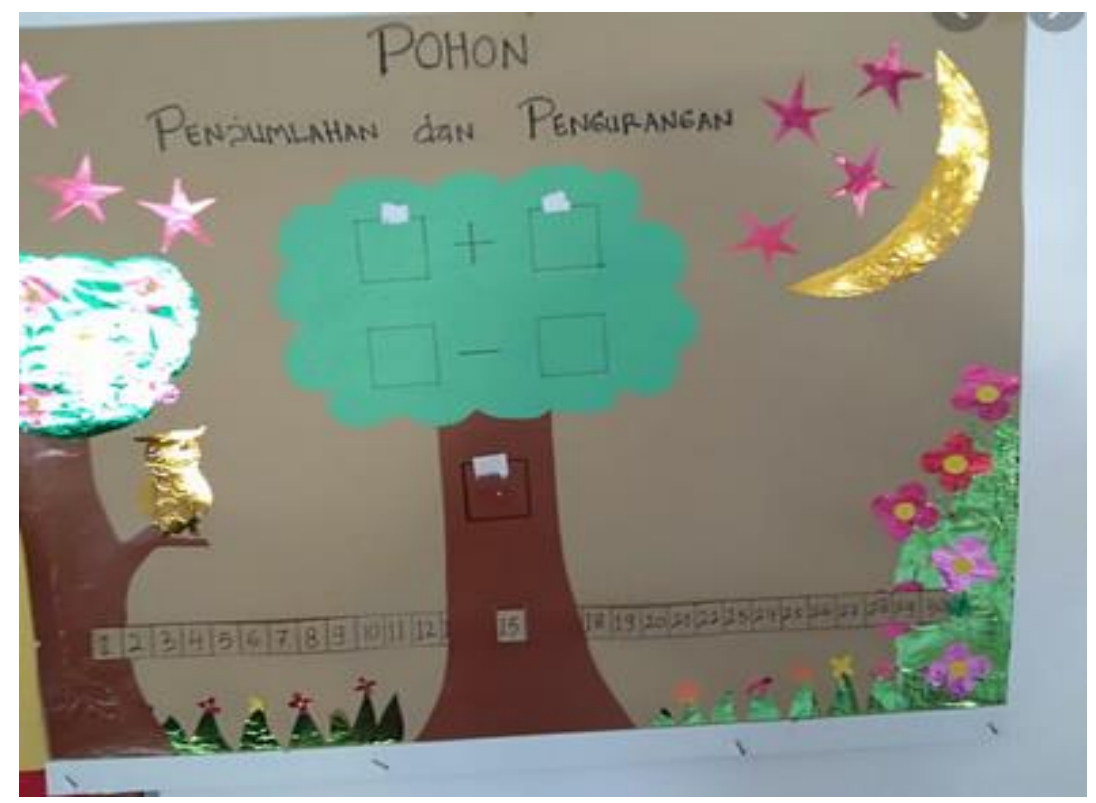

Gambar 1. Contoh Media Pohon Berhitung

\section{HASIL DAN PEMBAHASAN}

Kegiatan pengabdian masyarakat dalam bentuk pelaksanaan Kuliah Kerja Nyata (KKN), yang dilaksanakan secara mandiri oleh mahasiswa Universitas Flores, merupakan langkah baru diterapkan karena kondisi dunia yang mengalami pandemic covid 19. Mahasiswa melaporkan perkembangan kegiatan KKN setiap minggu menggunakan sistem e-learning dibawah pengawasan dan bimbingan Dosen Pembimbing Lapangan (DPL) dan juga Sipervisor. 
Kegiatan pengabdian di desa Ndetuzea berkaitan dengan inovasi pembelajaran dengan sasaran utama adalah siswa sekolah dasar kelas 1. Adapun hasil kegiatan pengabdian ini dapat dikelompokkan dalam 2 bagian, yaitu; persiapan dan pelaksanaan.

1. Persiapan Kegiatan Pengabdian

Beberapa hal yang harus dilakukan sebelum melaksanakan kegiatan pengabdian yaitu berkoordinasi dengan kepada desa untuk meminta izin pelaksanaan KKN serta menyampaikan maksud dan tujuan kegiatan. Hasil koordinasi dengan seluruh perangkat desa kemudian ditindaklanjuti dengan melaksanakan program-program sesuai tema masing-masing dari 7 orang mahasiswa Universitas Flores dengan program studi/jurusan yang beragam, baik dari pendidikan, pertanian, ekonomi dan juga hukum. Pada tema inovasi dan teknologi pembelajaran, persiapan awal yang dilakukan adalah berkoordinasi dengan orang tua dan guru terkait pelaksaan bimbingan belajar terhadap siswa, melakukan identivikasi untuk mengetahui permasalahan-permasalahan yang dialami siswa dalam kegiatan belajar dari rumah. Hasil identifikasi di lapangan menunjukkan beberapa permasalahan yaitu; a)guru belum menggunakan media pembelajaran, b) kurangnya bimbingan orang tua di rumah karena tidak ada waktu belajar yang ditentukan, c)kegiatan belajar dari rumah yang diatur guru belum berjalan maksimal sehingga banyak waktu digunakan siswa untuk bermain.

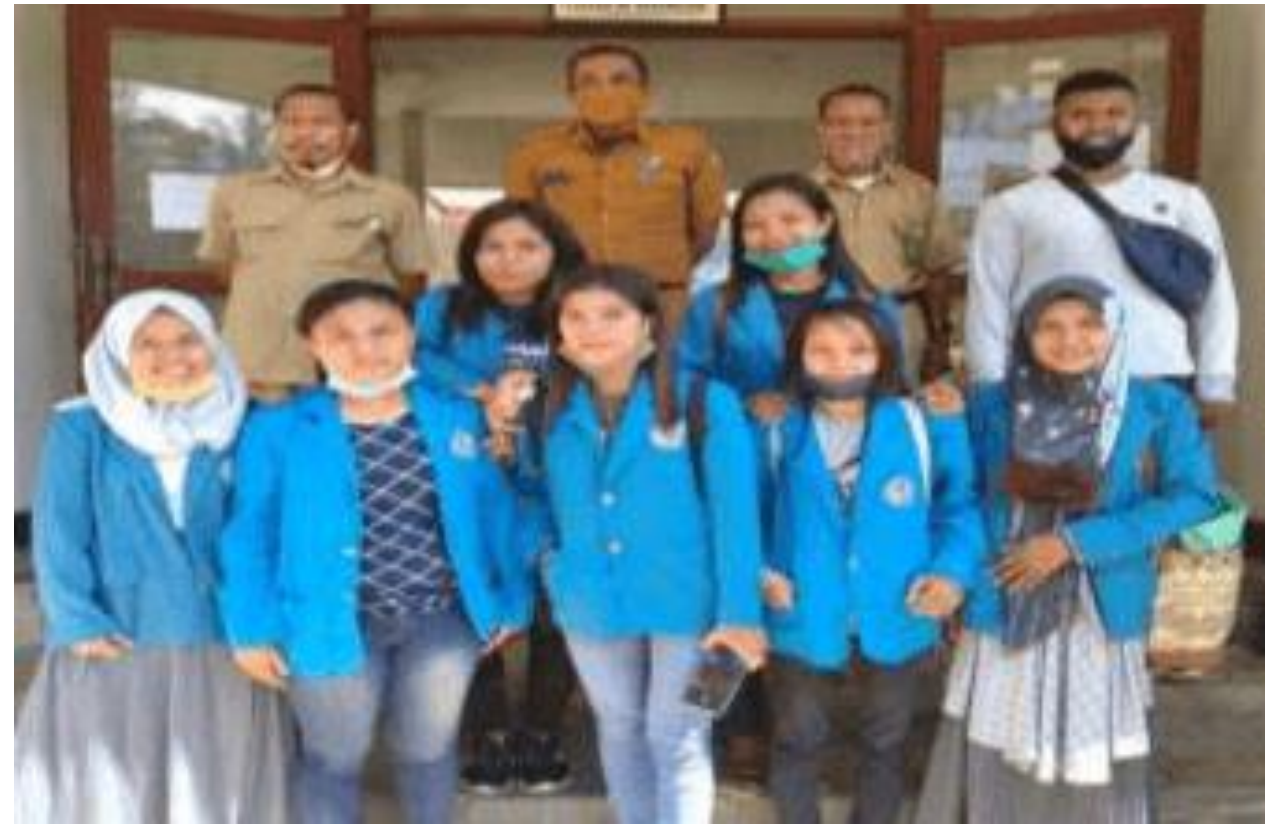

Gambar 2. Foto Bersama Perangkat Desa Ndetuzea Setelah Melakukan Koordinasi

Sesuai permasalahan yang dialami siswa/i sekolah dasar di desa Ndetuzea, maka solusi yang diambil adalah dengan membuat media pembelajaran yang dapat digunakan guru dan siswa. Media pembelajaran ini adalah pohon berhitung yang dapat dibuat dengan bahan-bahan yang ada di lingkungan desa dan mudah untuk dibuat. Selain itu media ini mudah diterapkan oleh orang tua dan secara mandiri dapat digunakan siswa saat belajar. Kegiatan lain yang juga dilakukan adalah membuat waktu belajar bagi siswa di rumah saat orang tua memiliki waktu bersama anak-anak baik di siang hari atau di malam hari. 


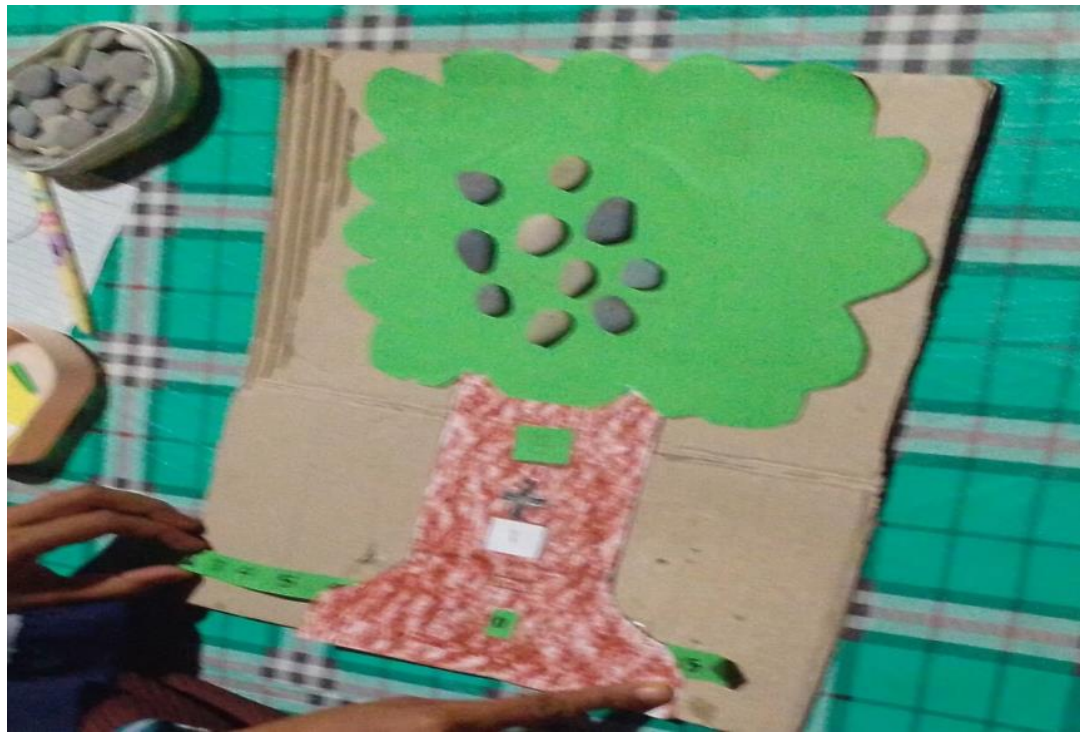

Gambar 3. Media Pembelajaran Pohon Berhitung

\section{Pelaksanaan Kegiatan Pengabdian}

Sesuai perencanaan kegiatan, hasil koordinasi bersama guru dan orang tua dan siswa, maka dibuatkan media pembelajaran pohon berhitung sebanyak dua buah sebagai alat bantu yang dapat digunakan dalam kegiatan pembelajaran. Selain itu disepakati pula jabwal belajar dari rumah yaitu setiap hari selasa, rabu dan hari Jum'at, dan juga membuat jadwal bimbingan sore sesuai kesepakatan dengan orang tua.

Media Pembelajaran (Pohon Berhitung) sedikit bisa membantu dan memberi pemahan kepada peserta didik bahwa materi berhitung pada mata pelajaran matematika itu tidak sulit atau susah seperti yang mereka pikirkan sebelumnya. Hasil yang mereka amati penjelasan dari saya mereka bisa mempraktekkan di rumahnya masing-masing,jadi Media pembelajaran ini sangat berperan penting pada proses belajar mengajar karena bisa memberikan motivasi dan pemahaman lebih kepada sisiwa,hasil kegiatan juga menunjukkan bahwa ada beberapa pengalaman baru yang diperoleh siswa dengan menggunakan media pohon penjumlahan.

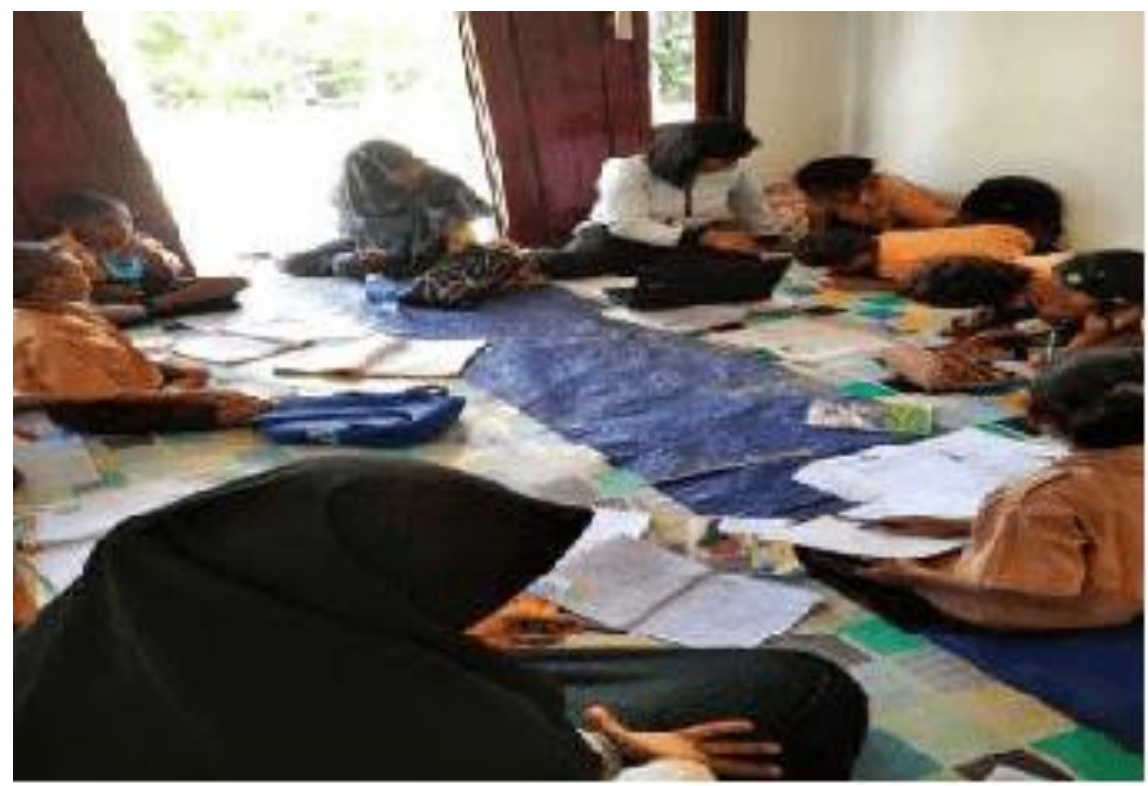

Gambar 4. Kegiatan Belajar Dari Rumah (BDR) 
Beberapa hasil penelitian membuktikan bahwa media pembelajaran pohon berhitung mampu meningkatkan kemampuan kognitif anak (Erlina, 2018; Susianie, 2013). Media sebagai alat komunikasi dapat lebih mengefektifkan proses belajar mengajar. Disamping mampu menggunakan alat-alat yang tersedia, guru juga dituntut untuk dapat mengembangkan keterampilan membuat media pembelajaran yang akan digunakannnya.

Bimbingan belajar pada sore hari juga memberikan manfaat atau dampak baik bagi siswa, karena anak didik mempunyai waktu yang banyak untuk bisa bertanya, berdiskusi dengan teman-temannya dan juga mengurangi waktu luang atau waktu bermainnya. Adapun jadwal bimbingan sore hari yang sudah disepakati oleh saya dan orang tua yaitu 3 hari dalam setiap minggu (Senin, Kamis dan Sabtu) mulai dari jam 16.00 - 18.00, dengan jumlah anggota 5 6 orang anak.

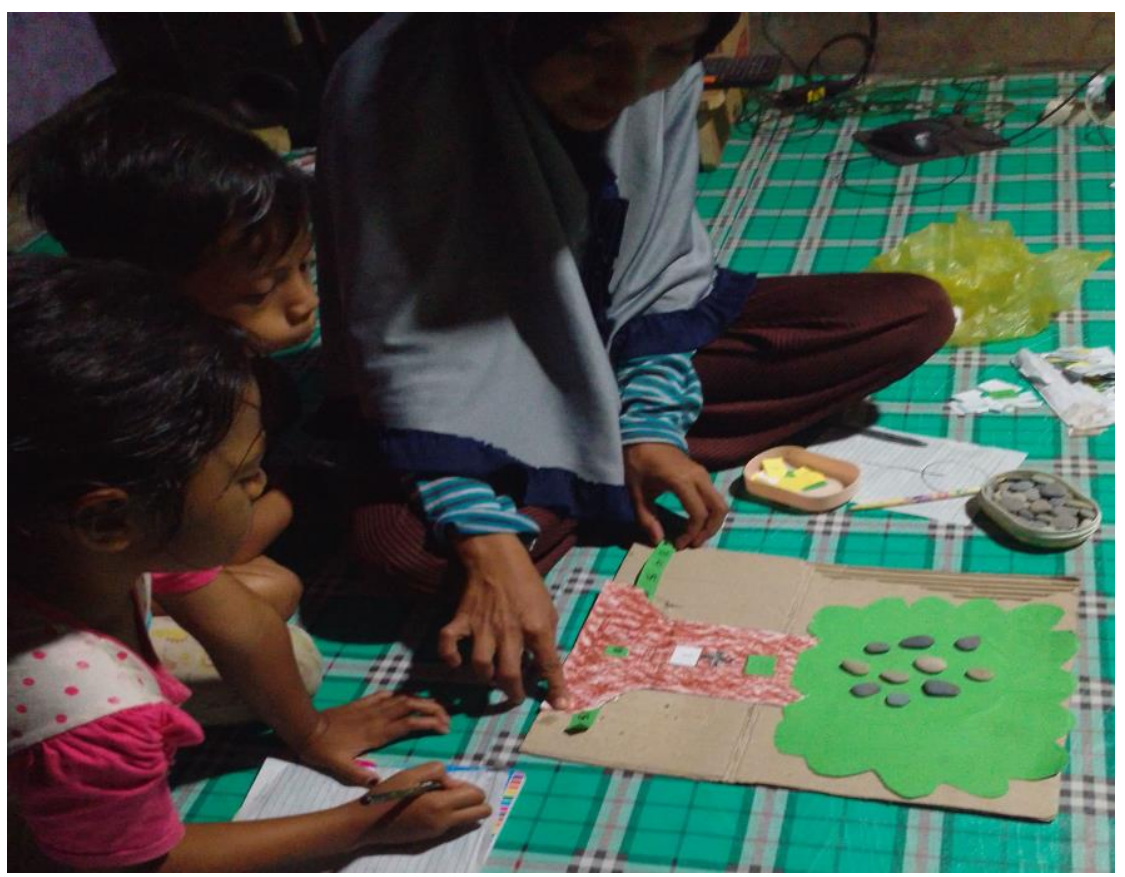

Gambar 5. Kegiatan Bimbingan di Rumah

\section{SIMPULAN DAN TINDAK LANJUT}

Beberapa simpulan yang dapat diambil dari kegiatan pengabdian di desa Ndetuzea adalah;

1) Melalui media pembelajaran pohon berhitung yang telah dibuat, maka siswa lebi aktif dan termotivasi untuk belajar.

2) Kegiatan belajar siswa lebih maksimal karena adanya jadwal bimbingan belajar yang telah disepakati bersama orang tua dan orang tua lebih memperhatikan anak dalam belajar.

Hasil kegiatan ini diharapkan dapat dijadikan contoh bagi guru dan orang tua siswa agar bisa memanfaatkan bahan atau lingkungan sebagai media belajar sehingga siswa termotivasi dan aktif dalam belajar,

\section{DAFTAR PUSTAKA}

Erlina, E. (2018). Meningkatkan Kemampuan Kognitif Mengurutkan Bilangan 1-10 Melalui Media Pohon Hitung Anak Kelompok B Di TK Baptis Setia Bakti Kota Kediri. PIJAR NUSANTARA. https://doi.org/10.29407/pn.v3i2.11867

Hernawan, A. H., Permasih, \& Dewi, L. (2008). Panduan Pengembangan Bahan Ajar. In Depdiknas 
Jakarta.

Mahnun, N. (2012). Media Pembelajaran (Kajian terhadap Langkah-langkah Pemilihan Media dan Implementasinya dalam Pembelajaran). An-Nida'.

Pane, A., \& Darwis Dasopang, M. (2017). BELAJAR DAN PEMBELAJARAN. FITRAH:Jurnal Kajian Ilmu-Ilmu Keislaman. https://doi.org/10.24952/fitrah.v3i2.945

Purnomo, H. (2013). Peran Orang Tua dalam Optimalisasi Tumbuh Kembang Anak untuk Membangun Karakter Anak Usia Dini. Prosiding Seminar Nasional Parenting.

SUSIANIE, A. (2013). PENERAPAN MEDIA POHON CERDAS UNTUK MENINGKATKAN KEMAMPUAN KOGNITIF ANAK DALAM BERHITUNG 1-10 KELOMPOK A DI TK DUNIA SUZAN RUNGKUT SURABAYA. PAUD Teratai.

Zaini, H., \& Dewi, K. (2017). PENTINGNYA MEDIA PEMBELAJARAN UNTUK ANAK USIA DINI. Raudhatul Athfal: Jurnal Pendidikan Islam Anak Usia Dini. https://doi.org/10.19109/ra.v1i1.1489

Zaman, B., Pd, M., \& Eliyawati, H. C. (2010). Media Pembelajaran Anak Usia Dini. In Media Pembelajaran Anak Usia Dini. 